\title{
Effect of bagasse ash and filter cake amendments on wheat (Triticum turgidum L.var. durum) yield and yield components in nitisol
}

\author{
Assefa Gonfa ${ }^{1} \cdot$ Bobe Bedadi $^{2} \cdot$ Anteneh Argaw $^{2}$
}

Received: 23 May 2017 / Accepted: 23 April 2018 / Published online: 4 May 2018

(c) The Author(s) 2018

\begin{abstract}
Purpose This experiment was initiated to evaluate the effect of filter cake and bagasse ash on the productivity of wheat under greenhouse conditions.

Methods Six levels of filter cake and bagasse ash each separately and control check were arranged in a completely randomized design with three replications.

Results At 100 tons/ha, both inputs resulted in the highest values of all the investigated traits. It was also found that yield and yield components that were obtained from bagasse ash overwhelmed those from filter cake treatments, except in tillers, dry biomass, and straw yield. Linear regression analysis revealed a significant and positive relationship between grain yield with that of total $\mathrm{N}, \mathrm{P}, \mathrm{K}, \mathrm{S}, \mathrm{Ca}, \mathrm{Mg}, \mathrm{Cu}$, and $\mathrm{Zn}$ uptake. A linear relationship between the grain yield with that of $\mathrm{N}$ and $\mathrm{Zn}$ uptake was found, while the association between grain yield with total $\mathrm{P}, \mathrm{K}, \mathrm{S}, \mathrm{Ca}, \mathrm{Mg}$ and $\mathrm{Cu}$ uptake was quadratic.

Conclusion It can be concluded that filter cake and bagasse ash are good sources of nutrients to enhance wheat yield in acidic soil. To give a conclusive result, these inputs should be tested in field trials in different soil types.
\end{abstract}

Keywords Bagasse $\cdot$ Ethiopia $\cdot$ Filter cake $\cdot$ Soil acidity $\cdot$ Subsistence farmers

\section{Introduction}

Durum wheat (Triticum turgidum $\mathrm{L}$ var. durum) is the most important cereal crop grown in Ethiopia. Ethiopia is believed to be the center of genetic diversity for wheat (Tesfaye and Getachew 1991). It is primarily produced by the smallholder farmers under rainfed conditions at altitudes ranging from 1800 to 2800 meters above sea level (Tesfaye 1987). Prior to 1954 , Ethiopia was an exporter of durum wheat grain and flour (Pinto 1971). However, consumer demand presently far exceeds domestic production and the country is even importing wheat products for the pasta industry.

Although many efforts have been made to develop high-yielding variety of wheat in Ethiopia, the productivity of wheat is still far below the potential yield reported

Anteneh Argaw

antenehargaw@gmail.com

1 Ethiopia Institute of Agricultural Research, Debre Zeit Agricultural Research Center, Debre Zeit, Ethiopia

2 College of Agriculture and Environmental Sciences, School of Natural Resources Management and Environmental Sciences, Haramaya University, Haramaya, Ethiopia elsewhere as a result of soil quality depletion and low soil fertility (Harden 2001; Lal 2001). The deficiency of some micronutrient besides widespread $\mathrm{N}$ and $\mathrm{P}$ (and localized $\mathrm{K}$ ) deficiencies in major wheat-growing areas of Ethiopian has been recently reported (Hailu et al. 2015). These problems are aggravated by continuous nutrient depletion due to the complete harvest of whole plant biomass and losses in runoff and soil erosion (Vlek 1993; Sanchez et al. 1997), which have led to negative nutrient balances (Stoorvogel and Smaling 1990). Crop yield per hectare has eventually decreased (Vierich and Stoop 1990). As a result, most of the soil in eastern Africa is less responsive as well as non-responsive to macronutrients like $\mathrm{N}$ (Bationo et al. 1986).

Agro-ecology-based production systems have promoted sustainable agricultural production systems (Altieri 1995; Gliessman 1998). Agricultural practices based on organic amendments are strongly recommended for tropical agroecosystems. The application of organic inputs to the soil is increasing as both an environmentally favorable and as a means of improving soil organic matter (SOM) content in low-fertility soils. Organic leftovers, namely, plant biomass, manure, and waste from urban, industrial, and agricultural activity are identified as valuable natural resources that can 
be effectively used for sustainable production and ecosystem restoration. Such organic inputs are useful inputs for the potential restoration of soil organic matter and increase inherent soil nutrient supply capacity (Fernandez-Luqueno et al. 2009; Nurhidayati et al. 2018) since manures are often scarce like in Ethiopia (Lupwayi et al. 2000). Organic byproducts originating from industrial processes represent an important source of nutrients for integrated soil fertility management.

Organic amendment could increase the soil P supplying capacity in acidic soils through increasing P mobility in the soil by chelating the soil $\mathrm{Al}$ and $\mathrm{Fe}$, thereby enhancing $\mathrm{P}$ acquisition by stimulation of root growth achieved by organic amendment (Kretzschmar et al. 1991). The organic amendment may also increase the soil $\mathrm{pH}$, the contents of exchangeable cations $(\mathrm{K}, \mathrm{Ca}, \mathrm{Mg})$ and the base saturation (Kretzschmar et al. 1991; Geiger et al. 1992). Maize grain yields tended to increase with increasing contents of soil C, total $\mathrm{N}$, extractable $\mathrm{P}$, and exchangeable bases as result of organic input application (Tittonell et al. 2007).

After combustion, most of the inorganic nutrients in biomass ash could be a significant source of $\mathrm{P}, \mathrm{K}, \mathrm{Mg}$ and $\mathrm{Ca}$ (Bougnom and Insam 2009; Bougnom et al. 2009). Biomass ash application could increase soil $\mathrm{pH}$ and stimulated bacterial activities that in turn increase decomposition rate of the humus layer, $\mathrm{N}$ mineralization, and $\mathrm{N}$ availability to plants (Fritze et al. 1994; Kreutzer 1995; Haimi et al. 2000). A significant increase in growth and yield of different crops due to biomass ash application has been reported (Odiete et al. 2005; Adekayode and Olojugba 2010; Gupta et al. 2010). For instance, biomass ash application resulted in a better increase in grain yields of barley (Hordeum vulgare L.), canola (Brassica rapa L.), and pea (Pisum sativum L.) when compared to the effect of agricultural lime have been reported (Arshad et al. 2012). However, the comparative advantage of filter cake and bagasse ash application on the productivity of wheat in acidic nitisol soil is not well known. Hence, the aim of this work was to evaluate the effect of filter cake and bagasse ash application on yield of wheat and to evaluate the relationship between the nutrients uptake with grain yield of wheat.

\section{Materials and methods}

A greenhouse experiment was performed on a silty clay soil classified as Eutric Nitisols, collected from the Endibir area (Central Ethiopia). For soil collection, the fields of 20 farmers were purposely selected based on the extent of soil acidity. Soil samples were collected from 0 to $20 \mathrm{~cm}$ depth at random from the fields of these 20 farmers and mixed well. The dried soil sample was passed through a 4-mm sieve to eliminate coarse rock and plant material and thoroughly mixed to ensure uniformity. A subsoil sample of about $1 \mathrm{~kg}$ was taken, air dried, and passed through a 2-mm sieve and used for the determination of physical and chemical characteristics. A part of the homogenized soil sample was ground to pass through a $0.5-\mathrm{mm}$ sieve for the analysis of $\mathrm{N}$, organic matter $(\mathrm{OM}), \mathrm{Cu}, \mathrm{Zn}, \mathrm{Fe}$ and $\mathrm{Mn}$ concentrations.

The soil was analyzed using standard procedure compiled by Sertsu and Bekele (2000). The soil had an average pH of 5.1 in a 1:2.5 soil-to-water ratio. The chemical composition of the soil before amendment contained 3.4\% OM, $0.16 \%$ total $\mathrm{N}, 10 \mathrm{mg} / \mathrm{kg}$ available $\mathrm{P}, 35.18 \mathrm{mg} / \mathrm{kg}$ available sulfur; $0.54 \mathrm{meq} / 100 \mathrm{~g}$ soil of exchangeable acidity $(\mathrm{Al}+\mathrm{H}) ; 44 \mathrm{mg} / \mathrm{kg}$ of Fe; $154 \mathrm{mg} / \mathrm{kg}$ of Mn; $0.56 \mathrm{mg} / \mathrm{kg}$ of $\mathrm{Cu} ; 2.40 \mathrm{mg} / \mathrm{kg}$ of $\mathrm{Zn}$, and $0.25,1.89,5.04$ and $2.80 \mathrm{cmol}$ $(+) / \mathrm{kg}$ exchangeable $\mathrm{Na}, \mathrm{K}, \mathrm{Ca}$ and $\mathrm{Mg}$, respectively. The textural composition of the soil was $9 \%$ sand, $45.5 \%$ silt and $45.5 \%$ clay with the bulk density of $1.27 \mathrm{gm} / \mathrm{cm}^{3}$. The volumetric soil water contents of the soil were 32 and $18 \%$ and $14 \%$ for field capacity, available water, and permanent wilting point, respectively.

Samples of both filter cake and bagasse ash were air dried and screened through a 2-mm sieve. Samples were sealed in polyethylene plastic containers until use for analysis or in the experiments. Triplicate samples from both filter cake and bagasse ash were analyzed for the selected chemical composition according to methods described for soil analysis. The chemical composition of both inputs is indicated in Table 1 .

The pot experiments were conducted on wheat under greenhouse conditions using cleaned plastic pots of $24 \mathrm{~cm}$ height and $25 \mathrm{~cm}$ width. Each pot contained $4 \mathrm{~kg}$ of soil. There were 11 treatments comprising 5 levels of filter cake application (20, 40, 60, 80 and 100 tons/ha) and 5 levels of bagasse ash application (20,40,60,80 and 100 tons/ha) separately, and the control check with 4 replications. Four replicates per treatment were established in a completely

Table 1 Chemical properties of filter cake and bagasse ash

\begin{tabular}{lll}
\hline Parameter & Filter cake & Bagasse ash \\
\hline $\mathrm{pH}\left(\mathrm{H}_{2} \mathrm{O}\right)$ & 8.0 & 10.2 \\
$\mathrm{EC}(\mathrm{ds} / \mathrm{m})$ & 1.70 & 3.90 \\
$\mathrm{OM}(\%)$ & 36.2 & 3.6 \\
$\mathrm{~N}(\%)$ & 1.77 & 0.17 \\
Available P $(\mathrm{mg} / \mathrm{kg})$ & 1.62 & 0.85 \\
Available S $(\mathrm{mg} / \mathrm{kg})$ & 1.67 & 1.29 \\
$\mathrm{~K}(\%)$ & 0.16 & 0.05 \\
$\mathrm{Ca}(\%)$ & 1.3 & 1.45 \\
$\mathrm{Mg}(\%)$ & 0.31 & 0.70 \\
$\mathrm{Fe}(\mathrm{mg} / \mathrm{kg})$ & 3 & 3 \\
$\mathrm{Mn}(\mathrm{mg} / \mathrm{kg})$ & 39 & 19 \\
$\mathrm{Cu}(\mathrm{mg} / \mathrm{kg})$ & 1.24 & 0.40 \\
$\mathrm{Zn}(\mathrm{mg} / \mathrm{kg})$ & 31.00 & 10.50 \\
\hline
\end{tabular}


randomized design (CRD). A total of 44 experimental units were used during the experiment.

The pot plants were harvested when physiologically matured. Samples of grain and straw collected at harvesting were oven-dried in an oven at $65{ }^{\circ} \mathrm{C}$ till a constant weight was obtained and then ground and passed through a 0.5 $\mathrm{mm}$ screen for chemical analysis. The uptake of selected macronutrients and micronutrients was calculated by multiplying the concentration of each nutrient by the dry weight expressed in $\mathrm{kg} / \mathrm{plant}$.

Agronomic data were collected and assessed to evaluate the effect of filter cake and bagasse ash on durum wheat. The agronomic parameters and yield and yield components determined are number of tillers, grain yield (GY), aboveground biomass, harvest index (HI), spike length, number of kernels per spike, number of spikelet per spike, and 1000 kernel weights of durum wheat. Plant root length was also taken by flushing with tap water to assess the effect of filter cake and bagasse ash on root length as it was affected by soil acidity.

All analyses were carried out on the four replicates. Treatment effects were analyzed by one-way analysis of variance (ANOVA). Data analysis was performed with SAS version 9.0. Data on soil, yield and yield traits of the crop were compared at a significance level of 0.05 . The means were separated by Tukey's test. Linear regression analysis of grain yields against nutrients uptake was performed to determine trends. The probability values of the slope indicated the level of significance of observed changes in yield.

\section{Results and discussion}

\section{Days of seedling emergence, heading, and physiological maturity}

The ANOVA showed that filter cake and bagasse ash application did not significantly $(P>0.05)$ affect days to $50 \%$ seedling emergence but these amendments significantly influenced days to $50 \%$ heading and $90 \%$ physiological maturity (Tables 2 and 3). At early vegetative growth stage, when the rate of filter cake increased, the treatments which received high rates of filter cake (80 and 100 tons/ha) showed slowness in growth (Table 4). The delaying of wheat growth at early vegetative stage could be due to immobilization of nutrients (Butler et al. 2001). At high rates of filter cake application, filter cake enhances the microbial growth (Kaur et al. 2008) and favors immobilization (Tejada et al. 2006) though the $\mathrm{C}: \mathrm{N}$ ratio $<15$, as indicated in Table 1 , should not occur immobilization (Powlson et al. 2001). In line with the present study, filter cake application enhanced $\mathrm{N}$ immobilization (Rasul et al. 2009). The rapid immobilization due to filter cake application might be due to the
Table 2 ANOVA data of filter cake treated agronomic parameters, yield and yield components

Table 3 ANOVA data of bagasse ash treated durum wheat agronomic parameters and yield and yield components

decomposition of an easily available carbohydrate fraction that may induce utilization of soil $\mathrm{N}$ by the soil microbial communities (Lentz and Ippolito 2012), thereby reducing the soil inorganic $\mathrm{N}$ (Khan et al. 2008). However, the plant that received high rates as well as low rates at 20 and 40 tons/ha of filter cake gradually showed good improvement over the control at a late stage of the plant.

Delaying in the days to $50 \%$ heading was also observed when the rates of filter cake increased. Likewise, days to physiological maturity was increased when filter cake application increased. The release of high $\mathrm{N}$ from the transiently immobilized $\mathrm{N}$ by the soil microbial biomass could be the cause of long days of $90 \%$ physiological maturity. Ellis and Cock (1992) found that excess N keeps vegetative growth, which results in delayed flowering and maturity. Bagasse ash treatments also recorded maximum days to $50 \%$ heading 
Table 4 Effect of filter cake and bagasse ash application on durum wheat phenology

\begin{tabular}{|c|c|c|c|}
\hline Treatment rates (t/ha) & $\begin{array}{l}\text { Days to } 50 \% \\
\text { emergence }\end{array}$ & $\begin{array}{l}\text { Days to } 50 \% \\
\text { heading }\end{array}$ & $\begin{array}{l}\text { Days } \\
\text { to } 90 \% \\
\text { maturity }\end{array}$ \\
\hline \multicolumn{4}{|l|}{ Filter cake } \\
\hline 0 & 4 & $60 \mathrm{a}$ & $88 \mathrm{e}$ \\
\hline 20 & 4 & $54 \mathrm{e}$ & $87 \mathrm{e}$ \\
\hline 40 & 4 & $55 \mathrm{~d}$ & $91 d$ \\
\hline 60 & 4 & $56 \mathrm{~cd}$ & $95 \mathrm{c}$ \\
\hline 80 & 4 & $56 \mathrm{cb}$ & $97 \mathrm{~b}$ \\
\hline 100 & 4 & $57 b$ & $101 \mathrm{a}$ \\
\hline $\operatorname{LSD}(0.05)$ & ns & 1.02 & 1.15 \\
\hline $\mathrm{CV}(\%)$ & & 1.20 & 0.82 \\
\hline \multicolumn{4}{|l|}{ Bagasse ash } \\
\hline 0 & 4 & $60 \mathrm{a}$ & $88.0 \mathrm{a}$ \\
\hline 20 & 4 & $53 b$ & $85.5 \mathrm{c}$ \\
\hline 40 & 4 & $53 b$ & $86.0 \mathrm{~b}$ \\
\hline 60 & 4 & $52 \mathrm{~d}$ & $86.5 \mathrm{ba}$ \\
\hline 80 & 4 & $51 \mathrm{~d}$ & $86.0 \mathrm{~b}$ \\
\hline 100 & 4 & $48 \mathrm{e}$ & $85.5 \mathrm{c}$ \\
\hline LSD (0.05) & ns & 0.98 & 0.54 \\
\hline $\mathrm{CV}(\%)$ & & 1.23 & 0.44 \\
\hline
\end{tabular}

Values along the column with the same letter are not significantly different at $\alpha=0.05$

(Table 3). When compared with filter cake, bagasse ash received plants showed lesser days to heading and physiological maturity. This difference may be due to more availability of plant nutrients at a reasonable time for bagasse ash application and having low nitrogen contents.

\section{Root length of durum wheat}

The data indicated that root length of experimental durum wheat was significantly and positively affected by filter cake and bagasse ash application (Table 5). Increasing rate of both inputs resulted in an increase in the root length of durum wheat. The highest value $(31.2$ and $28 \mathrm{~cm})$ was obtained at 100 and 60 tons/ha of filter cake and bagasse ash application, respectively. The lowest values were recorded at the control. From this, it could be concluded that filter cake application increased root length more than bagasse ash. This may be due to high $\mathrm{Ca}$ and $\mathrm{OM}$ content of filter cake that suppresses the availability of toxic elements such as $\left(\mathrm{Al}^{3+}\right)$ which affect root growth through precipitation and complex formation (Munoz et al. 1990). Calcium displaces $\mathrm{Al}$ from exchange sites and makes it form precipitation in the form of $\mathrm{Al}(\mathrm{OH})_{3}$ (Dee et al. 2002). Besides this, the filter cake could improve the soil physical properties and this may, in turn, facilitate the root growth.

\section{Effect of filter cake and bagasse ash application rates on agronomic parameters and yield and yield components of durum wheat}

Yield and yield components are soil fertility indicators and their positive response indicates the soil fertility improvement. Analysis of variance indicated that filter cake and bagasse ash rates application significantly affected the yield and yield components of wheat (Tables 2 and 3 ).

\section{Plant height, dry biomass, and number of tillers}

All treatments had shown positive response over the control in increasing plant height (Table 6). Dry biomass was significantly increased due to filter cake and bagasse ash application (Table 5). The maximum value was obtained with filter cake and bagasse ash application at 100 and 60 tons/ ha, respectively, while the minimum value was recorded at the control treatment. The finding corresponds to that of Jamil et al. (2004) that filter cake and bagasse application positively affected durum wheat dry biomass. In general, increasing the application rates of filter cake increased dry biomass. However, increasing bagasse ash rates did not bring significant differences among treatments in dry biomass except that all treatments brought higher values as compared to the control. These different effects on biomass production between two inputs investigated might be because of the presence of readily available nutrients in bagasse ash.

The numbers of tillers per plant were significantly increased due to filter cake application but inconsistently (Table 6). The lowest value was recorded at control. Due to high $\mathrm{N}$ and $\mathrm{P}$ content in filter cake, it induced a better number of tillers and dry biomass when compared with bagasse ash application.
Table 5 Effect of filter cake and bagasse ash on experimental wheat root length

\begin{tabular}{llllllllll}
\hline Treatment (t/ha) & 0 & 20 & 40 & 60 & 80 & 100 & Mean & LSD (5\%) & CV\% \\
\hline R. length, FC & $16.5 \mathrm{e}$ & $30 \mathrm{c}$ & $29 \mathrm{~d}$ & $31 \mathrm{bc}$ & $31.1 \mathrm{ba}$ & $31.2 \mathrm{a}$ & 28.08 & 0.72 & 1.70 \\
R. length, BA & $16.5 \mathrm{~d}$ & $22.3 \mathrm{c}$ & $25 \mathrm{~b}$ & $28 \mathrm{a}$ & $25 \mathrm{~b}$ & $25 \mathrm{~b}$ & 23.63 & 0.61 & 1.70 \\
\hline
\end{tabular}

Values with the same letter are not significantly different, $\mathrm{t} / \mathrm{ha}$, ton per hectare $F C$ filter cake, $R$. length root length (cm), $F C$ filter cake, $B A$ bagasse ash 
Table 6 Effect of filter cake and bagasse ash application on wheat yield and yield components

\begin{tabular}{|c|c|c|c|c|c|c|c|c|c|c|}
\hline Treatment rates (t/ha) & PLH (cm) & TIL (No) & $\mathrm{SPL}(\mathrm{cm})$ & SPLS (No) & KPS (No) & TKW (g) & $\mathrm{DBM}(\mathrm{g})$ & $\mathrm{SY}(\mathrm{g})$ & GY $(\mathrm{g})$ & $\mathrm{HI}$ \\
\hline \multicolumn{11}{|l|}{ Filter cake } \\
\hline 0 & $54.0 \mathrm{f}$ & $1.2 \mathrm{c}$ & $3.1 \mathrm{c}$ & $7.4 \mathrm{c}$ & $3.1 \mathrm{e}$ & $42.2 \mathrm{c}$ & $6.8 \mathrm{~d}$ & $5.9 \mathrm{~b}$ & $0.9 \mathrm{e}$ & $0.15 d$ \\
\hline 20 & $60.9 \mathrm{e}$ & $2.0 \mathrm{~b}$ & $3.8 \mathrm{~b}$ & $8.8 \mathrm{~b}$ & $10.1 d$ & 49.6ba & $9.6 \mathrm{c}$ & $6.5 b$ & $3.1 \mathrm{~d}$ & $0.37 \mathrm{c}$ \\
\hline 40 & $64.5 \mathrm{~d}$ & $2.8 \mathrm{a}$ & $4.0 \mathrm{ba}$ & $8.9 \mathrm{a}$ & $13.2 \mathrm{c}$ & $50.8 \mathrm{a}$ & $10.5 \mathrm{c}$ & $6.0 \mathrm{~b}$ & $4.6 \mathrm{c}$ & $0.47 \mathrm{a}$ \\
\hline 60 & $68.6 \mathrm{c}$ & $2.8 \mathrm{a}$ & 4.1ba & $8.9 \mathrm{a}$ & $14.4 \mathrm{~b}$ & $48.7 b$ & $13.6 \mathrm{~b}$ & $8.7 \mathrm{a}$ & $4.9 \mathrm{c}$ & $0.41 b c$ \\
\hline 80 & $72.5 b$ & $2.7 \mathrm{a}$ & $4.1 \mathrm{ba}$ & $8.8 \mathrm{a}$ & $15.3 b$ & $48.8 \mathrm{~b}$ & $13.2 b$ & $8.0 \mathrm{a}$ & $5.2 b$ & $0.45 \mathrm{ba}$ \\
\hline 100 & $75.0 \mathrm{a}$ & $2.7 \mathrm{a}$ & $4.4 \mathrm{a}$ & $8.8 \mathrm{a}$ & $17.2 \mathrm{a}$ & $49.4 \mathrm{ba}$ & $14.7 \mathrm{a}$ & $8.9 \mathrm{a}$ & $5.8 \mathrm{a}$ & $0.45 \mathrm{ba}$ \\
\hline Mean & 66.0 & 2.34 & 3.89 & 8.46 & 12.18 & 48.3 & 11.39 & 7.32 & 4.09 & 0.38 \\
\hline $\operatorname{LSD}(0.05)$ & 1.85 & 0.43 & 0.30 & 0.30 & 1.18 & 1.48 & 1.36 & 1.33 & 0.33 & 0.05 \\
\hline CV (\%) & 1.86 & 12.15 & 5.14 & 2.38 & 6.41 & 2.04 & 7.91 & 12.02 & 5.38 & 8.6 \\
\hline \multicolumn{11}{|l|}{ Bagasse ash } \\
\hline 0 & 54.0 & $1.2 \mathrm{c}$ & $3.1 \mathrm{~d}$ & $7.4 \mathrm{c}$ & $3.1 \mathrm{~d}$ & $42.6 \mathrm{e}$ & $6.8 \mathrm{~b}$ & $5.9 \mathrm{e}$ & $0.9 \mathrm{~d}$ & $0.15 d$ \\
\hline 20 & $64.9 \mathrm{e}$ & $2.5 \mathrm{a}$ & $3.9 \mathrm{c}$ & $9.13 b$ & $12.2 \mathrm{c}$ & $50.15 \mathrm{~d}$ & $10.9 \mathrm{a}$ & $7.1 \mathrm{c}$ & $3.9 \mathrm{c}$ & $0.41 \mathrm{c}$ \\
\hline 40 & $67.8 \mathrm{~d}$ & $2.6 \mathrm{a}$ & $4.1 b c$ & $8.88 b$ & $14.1 b$ & $51.4 \mathrm{c}$ & $12.1 \mathrm{a}$ & $7.6 \mathrm{a}$ & $4.6 \mathrm{~b}$ & $0.43 b c$ \\
\hline 60 & $71.9 \mathrm{c}$ & $1.7 \mathrm{~b}$ & $3.9 \mathrm{c}$ & $9.08 b$ & $15.1 \mathrm{ba}$ & $58.5 b$ & $12.4 \mathrm{a}$ & $7.3 b$ & $5.1 \mathrm{a}$ & $0.47 \mathrm{ba}$ \\
\hline 80 & $75.4 b$ & $1.45 \mathrm{cb}$ & $4.5 \mathrm{ba}$ & $9.53 \mathrm{a}$ & $15.8 \mathrm{a}$ & $60.7 a$ & $10.6 a$ & $5.4 \mathrm{f}$ & $5.2 \mathrm{a}$ & $0.50 \mathrm{ba}$ \\
\hline 100 & $79.5 \mathrm{a}$ & $1.65 b$ & $4.6 \mathrm{a}$ & $9.50 \mathrm{a}$ & $16.7 \mathrm{a}$ & $58.7 \mathrm{~b}$ & $11.7 \mathrm{a}$ & $6.7 d$ & $5.3 \mathrm{a}$ & $0.56 \mathrm{a}$ \\
\hline Mean & 68.95 & 1.84 & 4.00 & 8.85 & 12.81 & 53.7 & 10.79 & 6.52 & 4.17 & 0.42 \\
\hline LSD (0.05) & 2.52 & 0.44 & 0.46 & 0.37 & 1.61 & 0.71 & 1.96 & 0.13 & 0.42 & 0.09 \\
\hline CV (\%) & 2.43 & 15.81 & 7.65 & 2.79 & 8.46 & 0.86 & 12.08 & 1.31 & 6.67 & 14.14 \\
\hline
\end{tabular}

Values with the same letter are not significantly different at $\alpha=0.05$

PLH plant height; TIL tillers; SPL spike length; SPLS spikelet per spike; No number; KPS kernels per spike; TKW thousand kernels weight; $D B M$ dry biomass; $S Y$ straw yield; $G Y$ grain yield; $N o$ number/counting; $H I$ harvest index

\section{Spike length, spikelet per spike and kernels per spike}

The spike length, spikelet per spike and kernels per spike of durum wheat significantly increased as both inputs increased (Table 6). The maximum values were found at 100 tons/ ha with both inputs whereas the minimum at the control treatment. Bagasse ash application resulted in a better mean value of spike length, spikelet per spike and kernels per spike over filter cake applications though higher tiller number was obtained with plants treated filter cake than bagasse ash. This might have been related to the high availability of nutrients in bagasse ash treated plants besides maintaining soil pH at an acceptable level (Rautaray et al. 2003). These authors showed that high $\mathrm{K}, \mathrm{P}, \mathrm{Ca}$ and $\mathrm{Mg}$ nutrients uptake due to high available nutrients delivered through fly ash integrated with chemical and organic fertilizer leads to higher yield in rice. Other authors found the increase in grain yield of rice by ash application as result of enhancing the nutrient uptake (Mittra et al. 2005).

\section{Thousand kernels weight and straw yield}

Thousand kernels weight is an important yield-determining component, which is reported to be a genetic characteristic of a plant and influenced sparsely by the environmental factors (Ayoub et al. 1994). It was found that both inputs significantly increased 1000 kernels weight (Table 6). At 40 and 80 tons/ha, filter cake and bagasse ash application resulted in the highest kernel weight, respectively. The lowest value was recorded at control. The mean values for 1000 kernels weight of durum wheat, after the wheat treated with filter cake and bagasse ash application, were 48.3 and $53.7 \mathrm{~g}$, respectively. However, relatively higher 1000 kernels weight was obtained with filter cake when compared with bagasse ash treatment. This could be related to aphid and powdery mildew infection on the plants that received high rates of filter cake at maturity stage. High incidence of disease in filter cake amended plants might be due to the high $\mathrm{N}$ in the soil that may cause the plant to be more succulent and thus lead to susceptibility of the plants for disease.

The straw yield is another input response as well as an indicator of soil fertility status. The straw yield was significantly increased by filter cake and bagasse ash application (Table 6). The maximum value was recorded at 100 and 40 tons/ha for filter cake and bagasse ash application, respectively. The straw yield increased consistently with increasing application rate of filter cake but this trend along bagasse ash application rate was inconsistent. 


\section{Grain yield and harvest index}

The results of statistically analyzed data revealed that the filter cake and bagasse ash application regardless of the rates significantly increased the grain yield when compared to the control treatment (Table 6). The highest value was found at highest rates of application. The minimum values were recorded at the control treatment. The yield increment due to applying such input could be attributed to the increase in available nutrients and suitable soil condition to beneficial microbial proliferation and activities around the plant root zone (Demeyer et al. 2001; Rasul et al. 2008). Other studies showed that 60 tons/ha of filter cake application increased the yield of cassava by $50 \%$ over the mineral fertilization (Ossom 2010). Ossom and Dlamini (2012) found the comparable amount of maize grain yield by filter cake and recommended chemical fertilizer application. In general, wheat grain yield consistently increased as the rate of applied filter cake increased to the highest level but showed the tendency of stopping increment after 60 tons/ha for bagasse ash application. In previous studies, Thind et al. (2012) found that 10 tons/ha increased the yield of wheat by up to $43.7 \%$ over the unfertilized plants in the alkaline loamy sand.

Harvest index (HI) was significantly increased by filter cake and bagasse ash application (Table 6). The highest values ( 0.45 and 0.56$)$ were recorded at 100 tons/ha with filter cake and bagasse ash application, respectively, while the lowest values were obtained from control treatment. The value we have obtained in the present study after treatments, when compared with Hussians and Pan (1993) reported on average 0.34 for local cultivars and 0.44 for improved new varieties are high. Therefore, the highest values of harvest index (HI) in this study coincide with improved new varieties that were reported by Hussians and Pan (1993) as the experimental wheat was variety released from Debre Zeit Agricultural Research Center (DZARC) with the name "Yerer". In general, it was found that plants that were treated bagasse ash application had better HI when compared those treated filter cake applications.

\section{Regression analysis between grain yield of wheat and nutrients uptake}

The regression analysis between the grain yield and total uptake of selected macronutrients and micronutrients were significant at $P<0.05$ (Fig. 1a). Association between grain yield with $\mathrm{N}$ and $\mathrm{Zn}$ uptake was linear, implying that further increase in $\mathrm{N}$ and $\mathrm{Zn}$ uptake by applying inorganic fertilizer could improve the grain yield of wheat. This could be suggested that $\mathrm{N}$ and $\mathrm{Zn}$ the major limiting nutrients for wheat cultivation in the soil we used. This result indicates that organic fertilizer alone has not sufficiently supplied $\mathrm{N}$ to the plant (Herencia et al. 2007). With another nutrient uptake (P,
$\mathrm{S}, \mathrm{Ca}, \mathrm{Mg}$ and $\mathrm{Cu}$ ), grain yields exhibited quadratic relationship. This result could suggest that the rates below 100 tons/ ha could be sufficient, although further investigations under field condition are needed.

A significant $\left(P<0.05, r^{2}=0.95\right)$ association between grain yield and total $\mathrm{N}$ uptake with higher slope (2.783) for bagasse ash amended soils than the soil amended filter cake was demonstrated, implying the better effect of bagasse ash application on the total $\mathrm{N}$ uptake of wheat. The result might have been related with immobilization of native $\mathrm{N}$ by the high rate of filter cake application (Rautaray et al. 2003) and increase in $\mathrm{N}$ uptake by correcting the soil nutrients constraints through bagasse ash application (Aulakh and Malhi 2005). Ash application could also increase the decomposition of native soil organic matter through improving the microbial proliferation (Kaur et al. 2008) and activity (Lal et al. 1996), thereby improving the $\mathrm{N}$ availability (Wong and Wong 1986).

The association between grain yield and total $\mathrm{P}$ uptake were quadratic and significant $\left(P<0.05, r^{2}=0.96\right)$ with both inputs (Fig. 1b). In case of total $\mathrm{K}$ uptake and grain yield was significant $\left(P<0.05, r^{2}=0.94\right)$ and quadratic with a greater coefficient of the $x$-axis and $y$-intercept in plants that was amended bagasse ash than those amended filter cake (Fig. 1c). This result may indicate that bagasse ash could be a good source K for plants. Similar studies have shown that a strong association between $\mathrm{K}$ uptake and grain yield of wheat (Thind et al. 2012). Ash application increased the K availability in sandy loam acid lateritic soil (Rautaray et al. 2003). It was also found a significant $\left(P>0.05, r^{2}=0.96\right)$ and the quadratic relationship between grain yield and total S uptake (Fig. 1d).

In bagasse ash and filter cake amended soils, a linear and quadratic relationship between grain yield and total $\mathrm{Ca}$ uptake were found, respectively (Fig. 1e). This figure also indicated that the higher $y$-intercept was recorded in filter cake amended soil than bagasse ash amended soils. This result could be related to the presence of high $\mathrm{Ca}$ in filter cake compared to bagasse ash. Quadratic association $\left(P>0.05, r^{2}=0.97\right)$ between grain yield and total $\mathrm{Mg}$ uptake with a greater coefficient of $x$-axis and $y$-intercept was recorded when plants were treated with bagasse ash as compared with those treated with filter cake (Fig. 1f). This suggests that bagasse ash could be the good source of $\mathrm{Mg}$ when compared to the filter cake.

The relationship between grain yield and total $\mathrm{Cu}$ uptake was quadratic with a higher coefficient of the $x$-axis and $y$-intercept with plants treated bagasse ash than those with filter cake (Fig. 1g). Grain yield and total Zn uptake showed the linear association with higher $y$-intercept with bagasse ash amended plants than the filter cake amended plants (Fig. 1h), implying that bagasse ash is a good source of $\mathrm{Zn}$ and $\mathrm{Cu}$ when compared to the filter cake. Similar 
Fig. 1 Effect of filter cake and bagasse ash application rates on a Total $\mathrm{N}$ uptake, $\mathbf{b}$ Total $\mathrm{P}$ uptake, c Total K uptake, d Total $\mathrm{S}$ uptake, e Total Ca uptake, f Total Mg uptake, $\mathbf{g}$ Total $\mathrm{Cu}$ uptake and $\mathbf{h}$ Total $\mathrm{Zn}$ uptake of wheat under greenhouse condition
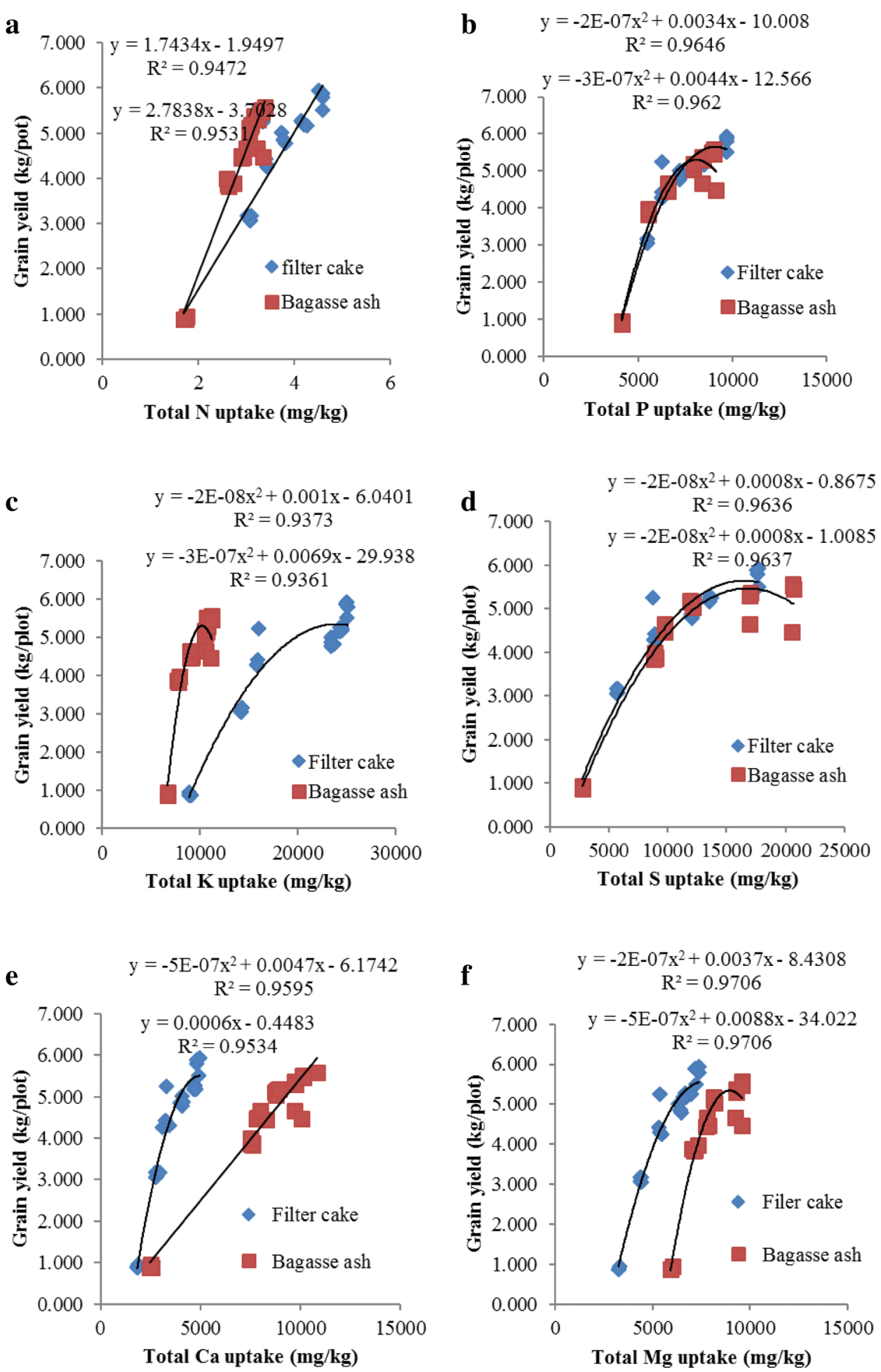

findings have been reported by Lentz and Ippolito (2012) who demonstrated that organic fertilizer with high nutrients content increased $\mathrm{Cu}, \mathrm{Zn}, \mathrm{S}, \mathrm{Mg}, \mathrm{K}$, and $\mathrm{N}$ concentration of silage corn by 1.3 fold when compared to the control.

\section{Conclusion}

In general, due to immobilization of nutrient when the applied high rate of the filter cake, incorporating filter 
Fig. 1 (continued)

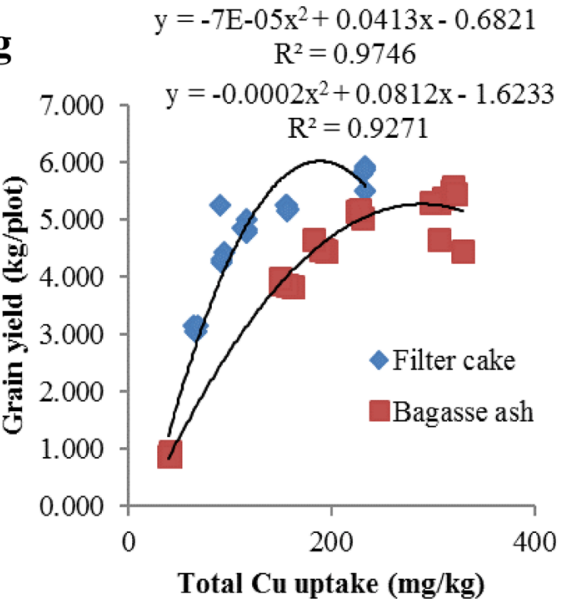

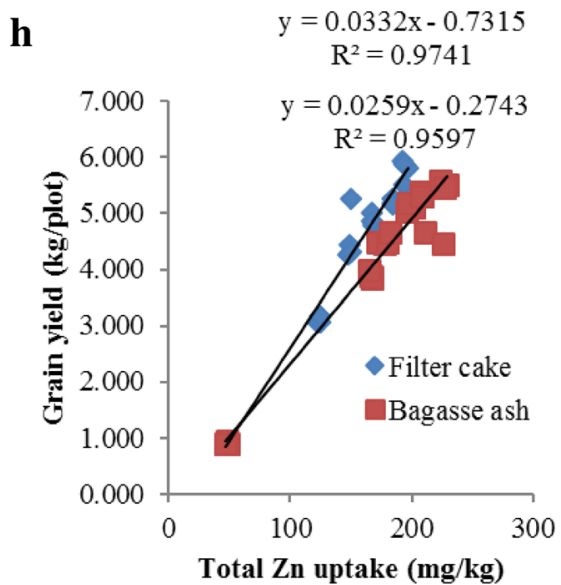

cake to the soil 1-2 months before sowing and undertaking decomposition before application to the soil is recommended. The result also found the need for relatively lower rate of bagasse ash when compared with filter cake to enhance wheat production in acidic and low fertile soils. To give a conclusive result for the end user and to finetune the rate for practical implementation, further research work under field conditions is needed. In general, the awareness of amending the acidic soil with filter cake and bagasse ash application, besides lime application, could correct the soil $\mathrm{pH}$ into acceptable range and improve the soil nutrients as well.

Acknowledgements The authors would like to acknowledge Ethiopian Institute of Agricultural Research (EIAR) for financial support, Matahara sugar Estate Farm for free support of organic inputs (filter cake and bagasse ash), and Haramaya University (HU) for facility support during my stay in the University Campus. Our acknowledgement also goes to Debre Zeit Agricultural Chemistry Laboratory for its full support in laboratory analytical service.

Open Access This article is distributed under the terms of the Creative Commons Attribution 4.0 International License (http://creativeco mmons.org/licenses/by/4.0/), which permits unrestricted use, distribution, and reproduction in any medium, provided you give appropriate credit to the original author(s) and the source, provide a link to the Creative Commons license, and indicate if changes were made.

\section{References}

Adekayode FO, Olojugba MR (2010) The utilization of wood ash as manure to reduce the use of mineral fertilizer for improved performance of maize (Zea mays L.) as measured in the chlorophyll content and grain yield. J Soil Sci Environ Manag 1:40-45

Altieri MA (1995) Agroecology: the science of sustainable agriculture. Ann Arbor Press, Michigan

Arshad MA, Soon YK, Azooz RH, Lupwayi NZ, Chang SX (2012) Soil and crop response to wood ash and lime application in acidic soils. Agron J 104:715-721. https://doi.org/10.2134/agronj2011.0355
Aulakh MS, Malhi SS (2005) Interactions of nitrogen with other nutrients and water: effect on crop yield and quality, nutrient use efficiency, carbon sequestration, and environmental pollution. Adv Agron 86:342-409. https://doi.org/10.1016/S0065 $-2113(05) 86007-9$

Ayoub M, Guertin S, Lussier S, Smith DL (1994) Timing and levels of nitrogen fertility effects on spring wheat. Crop Sci 34:748-750. https://doi.org/10.2135/cropsci1994.0011183X003400030027x

Bationo A, Mughogho SK, Mokwunye AU (1986) Agronomic evaluation of phosphate fertilizer in tropical Africa. In: Mokwunye AU, Vlek PLG (eds) Management of nitrogen and phosphorus fertilizers in Sub-Saharan Africa developments in plant and soil sciences, 24th edn. Martinus Nijhoff Publishers, Dordrecht, pp 283-318

Bougnom BP, Insam H (2009) Ash additives to compost affect soil microbial communities and apple seedling growth. Bodenkultur 60:5-15

Bougnom BP, Mair J, Etoa FX, Insam H (2009) Composts with wood ash addition: a risk or a chance for ameliorating acid tropical soils? Geoderma 153:402-407. https://doi.org/10.1016/j.geode rma.2009.09.003

Butler TA, Sikora LJ, Steinhilber PM, Douglass LW (2001) Compost age and sample storage effects on maturity indicators of biosolids compost. J Environ Qual 30(6):2141-2148. https://doi. org/10.2134/jeq2001.2141

Dee BM, Haynes RJ, Meyer JH (2002) Sugar mill wastes can be important soil amendments. Proc S Afr Sugarcane Technol Assoc 76:51-60

Demeyer A, Nkana JCV, Verloo MG (2001) Characteristics of wood ash and influence on soil properties and nutrient uptake: an overview. Bioresour Technol 77:287-295. https://doi.org/10.1016/ S0960-8524(00)00043-2

Ellis BG, Cock RL (1992) Soil management a world view of conservation. Krieger publish company, Malabar

Fernandez-Luqueno F, Reyes-Varela V, Martinez-Suare ZC, ReynosoKeller RE, Mendez-Bautista J, Ruíz-Romero E, Lopez-Valdez F, Luna-Guido ML, Dendooven L (2009) Emission of $\mathrm{CO}_{2}$ and $\mathrm{N}_{2} \mathrm{O}$ from soil cultivated with common bean (Phaseolus vulgaris L.) fertilized with different N sources. Sci Total Environ 407:42894296. https://doi.org/10.1016/j.scitotenv.2009.04.016

Fritze H, Smolander A, Levula T, Kitunen V, Mälkönen E (1994) Wood ash fertilization and fire treatments in a Scots pine forest stand: effects on the organic layer, microbial biomass and microbial activity. Biol Fertil Soils 17:57-63

Geiger SC, Manu A, Bationo A (1992) Changes in a sandy Sahelian soil following crop residue and fertilizer additions. Soil Sci Soc 
Am J 56:172-177. https://doi.org/10.2136/sssaj1992.0361599500 $5600010027 \mathrm{x}$

Gliessman SR (1998) Agroecology: ecological process in sustainable agriculture. Ann Arbor Press, Michigan

Gupta AK, Mishra RK, Sinha S, Lee BK (2010) Growth, metal accumulation and yield performance of Brassica campestris L. (cv. Pusa Jaikisan) grown on soil amended with tannery sludge/fly ash mixture. Ecol Eng 36:981-991. https://doi.org/10.1016/j.ecole ng.2010.04.003

Hailu H, Mamo T, Keskinen R, Karltun E, Gebrekidan H, Bekele T (2015) Soil fertility status and wheat nutrient content in Vertisol cropping systems of central highlands of Ethiopia. Agric Food Secur 4:19. https://doi.org/10.1186/s40066-015-0038-0

Haimi J, Fritze H, Moilanen P (2000) Responses of soil decomposer animals to wood-ash fertilization and burning in a coniferous forest stand. Forest Ecol Manag 129:53-61. https://doi. org/10.1016/s0378-1127(99)00158-9

Harden CP (2001) Soil erosion and sustainable mountain development: experiments, observations, and recommendations from the Ecuadorian Andes. Mt Res Dev 21:77-83. https://doi. org/10.1659/0276-4741(2001)021[0077:seasmd]2.0.co;2

Herencia JF, Ruiz-Porras JC, Melero S, Garcia-Galavis PA, Morillo $\mathrm{E}$, Maqueda C (2007) Comparison between organic and mineral fertilization for soil fertility levels, crop macronutrient concentrations, and yield. Agron J 99:973-983. https://doi. org/10.2134/agronj2006.0168

Hussians DR, Pan WL (1993) Nitrogen efficiency components analysis: an evaluation of cropping systems difference in productivity. Agron J 85:898-905. https://doi.org/10.2134/agronj1993.00021 962008500040022x

Jamil M, Qasim M, Umar M, Subhan Abdus (2004) Impact of organic wastes (bagasse ash) on the yield of wheat (Triticum aestivum L.) in a calcareous soil. Int J Agri Biol 6(3):468-470

Kaur K, Goyal S, Kapoor KK (2008) Impact of organic fertilizers with and without chemical fertilizers on soil chemical properties and the establishment of nitrogen-fixing bacteria in the rhizosphere. Microbes Environ 23(4):313-316

Khan KS, Gattinger A, Buegger F, Schloter M, Joergensen RG (2008) Microbial use of organic amendments in saline soils monitored by changes in the ${ }^{13} \mathrm{C} /{ }^{12} \mathrm{C}$ ratio. Soil Biol Biochem 40:1217-1224. https://doi.org/10.1016/j.soilbio.2007.12.016

Kretzschmar RM, Hafner H, Bationo A, Marschner H (1991) Longand short-term effects of crop residues on aluminum toxicity, phosphorus availability and growth of pearl millet in an acid sandy soil. Plant Soil 136:215-223

Kreutzer K (1995) Effects of liming on soil processes. Plant Soil 168-169:447-470

Lal R (2001) World crop land soils as source or sink for atmospheric carbon. Adv Agron 71:145-191. https://doi.org/10.1016/s0065 -2113(01)71014-0

Lal JK, Mishra B, Sarkar AK (1996) Effect of fly ash on soil microbial and enzymatic activity. J Indian Soc Soil Sci 44:77-80. https://doi.org/10.1016/0143-1471(86)90080-2

Lentz RD, Ippolito JA (2012) Biochar and manure affect calcareous soil and corn silage nutrient concentrations and uptake. J Environ Qual 41:1033-1043. https://doi.org/10.2134/jeq2011.0126

Lupwayi NZ, Girma M, Haque I (2000) Plant nutrient content of cattle manures from smallscale farms and experimental stations in the Ethiopian highlands. Agr Ecosyst Environ 78:57-63

Mittra BN, Karmakar S, Swain DK, Ghosh BC (2005) Fly ash a potential source of soil amendment and a component of integrated plant nutrient supply system. Fuel 84:1447-1451. https ://doi.org/10.1016/j.fuel.2004.10.019

Munoz MA, Colberg O, Dumas JA (1990) Chicken manure as an organic fertilizer. J Agric Univ P R 74:139-144
Nurhidayati N, Machfudz M, Murwani I (2018) Direct and residual effect of various vermicompost on soil nutrient and nutrient uptake dynamics and productivity of four mustard $\mathrm{Pak}^{-} \mathrm{Coi}$ (Brassica rapa L.) sequences in organic farming system. Int J Recycl Org Waste Agric. https://doi.org/10.1007/s4009 3-018-0203-0

Odiete I, Chude VO, Ojeniyi SO, Okozi AA, Hussaini GM (2005) Response of maize to nitrogen and phosphorus sources in Guinea savanna zone of Nigeria. Niger J Soil Sci 15:90-101

Ossom EM (2010) Effects of filter cake fertilization on weed infestation, disease incidence and tuber yield of cassava (Manihot esculenta) in Swaziland. Int J Agric Biol 12(1):45-50

Ossom EM, Dlamini FT (2012) Effects of filter cake on soil mineral nutrients and maize (Zea mays L.) agronomy. J Trop Agric 89(3):141-150

Pinto FF (1971) Current wheat situation in Ethiopia. In: Proceedings of the first wheat workshop. El Batan, Mexico, D.F: CIMMYT, pp 21-24

Powlson DS, Hirsch PR, Brookes PC (2001) The role of soil microorganisms in soil organic matter conservation in the tropics. Nutr Cycl Agroecosyst 61:41-51

Rasul G, Khan KS, Müller T, Joergensen RG (2008) Soil-microbial response to sugarcane filter cake and biogenic waste compost. J Plant Nutr Soil Sci 171:355-360. https://doi.org/10.1002/ jpln.200700094

Rasul G, Khan AA, Khan KS, Joergensen RG (2009) Immobilization and mineralization of nitrogen in a saline and alkaline soil during microbial use of sugarcane filter cake amended with glucose. Biol Fertil Soils 45:289-296. https://doi.org/10.1007/s0037 4-008-0333-z

Rautaray SK, Ghosh BC, Mittra BN (2003) Effect of fly ash, organic wastes and chemical fertilizers on yield, nutrient uptake, heavy metal content and residual fertility in a rice-mustard cropping sequence under acid lateritic soils. Bioresour Technol 90:275283. https://doi.org/10.1016/S0960-8524(03)00132-9

Sanchez PA, Sheperd KD, Soule MJ, Place FM, Buresh RJ, Izac AM, Mokwunye AV, Kwesiga FR, Ndiritu CG, Woomer PL (1997) Soil fertility replenishment in Africa: an investment in natural resource capital. In: Buresh RJ et al (eds) Replenishing soil fertility in Africa, 51st edn. SSSA Spec. Publ., Madison, pp 1-46

Sertsu S, Bekele T (2000) Procedures for soil and plant analysis. National Soil Research Center. EARO, Addis Ababa, pp 15-23

Stoorvogel JJ, Smaling EMA (1990) Assessment of soil nutrient depletion in sub-Saharan Africa, 1983-2000. Rep. 28. Win and Staring Center for Integrated Land, Soil and Water Res., Wageningen

Tejada M, Garcia C, Gonzalez JL, Hernandez MT (2006) Organic amendment based on fresh and composted beet vinasse: influence on soil properties and wheat yield. Soil Sci Soc Am J 70:900-908. https://doi.org/10.2136/sssaj2005.0271

Tesfaye T (1987) Durum wheat breeding in Ethiopia. In: van Ginkel, M, Tanner DG (eds). In: Fifth regional wheat workshop for Eastern, Central and Southern Africa and the Indian Ocean. D.F. Mexico, CIMMYT, pp 18-22

Tesfaye T, Getachew B (1991) Aspects of Ethiopian tetraploid wheats with emphasis on durum genetics and breeding research. In: Mariam HG, Tanner DG, Hulluka M et al (eds) Wheat research in Ethiopia: a historical perspective. IAR/CIMMYT, Addis Ababa, pp 47-71

Thind HS, Singh Y, Singh B, Singh V, Sharma S, Vashistha M, Singh G (2012) Land application of rice husk ash, bagasse ash and coal fly ash: effects on crop productivity and nutrient uptake in rice-wheat system on an alkaline loamy sand. Field Crop Res 135:137-144. https://doi.org/10.1016/j.fcr.2012.07.012

Tittonell P, Vanlauwe B, De Ridder N, Giller KE (2007) Heterogeneity of crop productivity and resource use efficiency within 
smallholder Kenyan farms: soil fertility gradients or management intensity gradients? Agr Syst 94:376-390. https://doi. org/10.1016/j.agsy.2006.10.012

Vierich HID, Stoop WA (1990) Changes in West African savannah agriculture in response to growing population and continuing low rainfall. Agr Ecosyst Environ 31:115-132. https://doi. org/10.1016/0167-8809(90)90214-X

Vlek PLG (1993) Strategies for sustaining agriculture in sub-Saharan Africa. In: Rogland J, Lal R (eds) Technologies for sustaining agriculture in the tropics, 56th edn. ASA Spec. Publ., Madison, pp 265-277
Wong MH, Wong JWC (1986) Effects of fly ash on soil microbial activity. Environ Pollut Ser A Ecol Biol 40:127-144. https://doi. org/10.1016/0143-1471(86)90080-2

Publisher's Note Springer Nature remains neutral with regard to jurisdictional claims in published maps and institutional affiliations. 